\title{
Study of the Composition, Fuel Parameter and Triangular Graph of a Gasoline and Aqueous Ethanol Fuel Blend in a Single Phase
}

\author{
HANNY F. SANGIAN ${ }^{1 *}$, ANITA R. IBRAHIM ${ }^{1}$, HANDY I. R. MOSEY ${ }^{1}$, \\ JOSHUA R. ROMBANG ${ }^{1}$, ADEY TANAUMA ${ }^{1}$, GUNTUR PASAU ${ }^{1}$, \\ SENI H. TONGKUKUT ${ }^{1}$, FINGKEN SAGAI ${ }^{1}$, RONNY PURWADI ${ }^{2}$, \\ GODLIEF F. NEONUFA ${ }^{3}$, JOHNLY A. RORONG ${ }^{4}$, ARIEF WIDJAJA ${ }^{5}$, \\ ABUBAKAR TUHULOULA ${ }^{6}$, RAMLI THAHIR ${ }^{7}$, BAYU ACHIL SADJAB $^{8}$, \\ VECKY A. J. MASINAMBOW ${ }^{9}$, TUN SRIANA ${ }^{10}$, ZAMI FURQON ${ }^{10}$, \\ SILVYA Y. AGNESTY10 \\ ${ }^{1}$ Department of Physics, Sam Ratulangi University, 95115, Manado, Indonesia \\ ${ }^{2}$ Department of Chemical Engineering, Institut Teknologi Bandung, 40132, Bandung, Indonesia \\ ${ }^{3}$ Department of Agriculture Product Technology, UKAW Kupang, Indonesia \\ ${ }^{4}$ Department of Chemistry, Sam Ratulangi University, 85361, Manado, Indonesia \\ ${ }^{5}$ Department of Chemical Engineering, Institut Teknologi Sepuluh Nopember, 60111, Surabaya, Indonesia \\ ${ }^{6}$ Department of Chemical Engineering, Lambung Mangkurat University, 70124, Banjarbaru, Indonesia \\ ${ }^{7}$ Department of Chemical Engineering, Politeknik Negeri Samarinda, 75136, Samarinda, Indonesia \\ ${ }^{8}$ Department of Physics, Halmahera University, North Maluku, 97762, Tobelo, Indonesia \\ ${ }^{9}$ Department of Economic Development, Sam Ratulangi University, 95115, Manado, Indonesia \\ ${ }^{10}$ Department of Oil and Gas Processing Engineering, Polytechnic of Energy and Minerals, 58315, Cepu Blora, Indonesia
}

\begin{abstract}
This study investigates the composition and fuel parameters of a fuel blend of aqueous ethanol and gasoline, with RONs (Research Octane Numbers) of 90 and 92, called pertalite and pertamax in Indonesia, respectively. The emulsion fuel blend of gasoline and ethanol was prepared successfully, and the concentrations ranged from 80 to $98 \%(v / v)$. The steps employed in this work are as follows: first, the fermentation of sugar tapped from a palm tree (Arenga pinnata). The obtained liquor containing ethanol was distilled using a reflux still to separate ethanol and water. The purity of the ethanol obtained from the reflux process ranged from 80 to $96 \%$, depending on the column temperature set. Ethanol solutions of 97 and $98 \%$ purities were obtained through an absorption method employing lime particles. Subsequently, aqueous ethanol was blended with gasoline manually inside a flask. It was discovered that the minimum ethanol concentration, which could be blended with pertalite to form a single-phase substance, was $80 \%$. By using $80 \%$ ethanol in the blending process, the composition ratio of pertalite, pure ethanol, and water was recorded as 1:11.65:2.91 (in volume unit), while this was not the case with pertamax. The minimum ethanol concentration that could be blended with pertamax to form a single-phase emulsion was $88 \%$, with a composition ratio of 1:5.91:0.81. The composition proportions of the three components with 96\% ethanol were 1:0.27:0.01 (RON 90) and 1:0.41:0.02 (RON 92). It was observed that the higher the ethanol concentration, the less the amount of ethanol required for the blending process with gasoline to form a single-phase emulsion.
\end{abstract}

Keywords: composition, emulsion, ethanol, gasoline

\section{Introduction}

Currently, scientists are devoting intensive effort to the conversion of renewable resources, including lignocellulose (biomass) into valuable materials, such as ethanol [1-2], sugar [3-5], gas [6] and hydrogen [7]. The biofuels derived from these materials, which provide renewable energy, have been investigated to overcome the issue of decreasing reserves of fossil-based fuels [8-11].

\footnotetext{
*email: hannysangian@yahoo.co.id
} 
Emulsion fuel was invented some years ago and has since been applied in heat machines. However, it has not been utilized globally because it is expensive. The most challenging aspect of developing an emulsion fuel is the global unavailability of raw materials for ethanol production.

Only the United States of America and Brazil have succeeded in producing emulsion fuels, particularly gasohol, on account of their abundant corn and sugarcane productions [12-13]. Meanwhile, Indonesia has reported the most success with the usage of blended fuel, diesel, and biodiesel derived from palm oil [14].

Absolute ethanol is generally used in alcohol-fossil-based oil blends, and it is prepared through a complicated technique, which makes it more expensive than gasoline [15].The fuel blends, particularly gasohol, is employed as the primary energy source in Brazil and has been integrated into the nation's economy and social development [16]. Through national policies, the country strives to achieve oil exportation to increase revenue and enhance the rural areas' economy by widening the sugarcane industry.

The ethanol and gasoline fuel blend should be well understood in terms of its characteristics, performance, and the gases emission in machines, particularly the spark-ignition engine, which was investigated by previous works [17]. Generally, employing $10 \%$ ethanol in fuel blends results in improved performance. However, the $\mathrm{CO}_{2}$ emission is higher than that for pure gasoline, while reduced $\mathrm{CO}$ emission is achieved.

Another research reported similar trends, in which the performance of an engine employing an ethanol and gasoline blend (10\% and 20\% (v/v)) increased, while emission decreased [18]. The separative property of the gasoline and ethanol fuel blend has also been investigated, as reported by previous authors [19].

Investigations into the application of gasoline and ethanol blends as fuel have been conducted and reported recently. The tolerance of the water content in fuel blends contained in a tank altered the temperature 283.15, 293.15, and 313.15 K [20]. The result showed that the lesser the fuel content in the container, the smaller the ethanol and water contents detected due to their polarity. The emulsion fuel blend of gasoline, and ethanol, was developed and applied in a heat machine as previously reported [21]. The work investigated the performance and emissions of a machine using a blended fuel mixture of ethanol and gasoline while also comparing them with those of the engine using pure gasoline.

A study on the emulsion fuel blend of ethanol and gasoline with a RON of 88 was conducted previously [22]. Authors [23-24] reported obtaining a blended fuel (gasoline and ethanol) with a technical ethanol concentration of $96 \%$. Increasing the amount of ethanol in fuel could increase the research octane number (RON), substance density, and kinematics. When the ethanol content in fuel is decreased, the API gravity and heat quantities are also reduced, while other properties such as cloud, flash, and fire points are increased.

The present study investigates the compositions of gasoline with RONs of 90 and 92, and aqueous ethanol formed in a single phase. This work started with the fermentation of sugar tapped from an Arenga pinnata tree. It proceeded with the separation of water and ethanol by distillation using a reflux separator, where the equipped column was packed with natural materials.

The ethanol concentrations were varied from 80 to $96 \%$ and were influenced by the column temperature. Conversely, ethanol solutions of 97 and $98 \%$ concentrations were obtained by an adsorption technique. Each aqueous ethanol was blended with gasoline until all the components combined to form a single-phase stable emulsion.

\section{Materials and methods}

\subsection{Materials preparation}

Ethanol (80-96 \% v/v) was derived from Arenga pinnata which sugar, which was fermented employing a reflux distillation. Meanwhile, ethanol $97-98 \%$ were obtained by using a sieve molecule 
technique using an activated lime. Gasoline (RONs of 90 and 92) were purchased from The State Oil and Gas Company of Indonesia (PERTAMINA).

\subsection{The blending}

Firstly, gasoline with RONs of 90 and 92 was poured into $7 \mathrm{~mL}$ flasks; afterward, ethanol was added gradually until a uniform single-phase mixture was obtained. Initially, two components could be discriminated against from the mixture; however, as the ethanol composition increased steadily, the gasoline component decreased until an indistinguishable uniform blend was obtained. All data collected were observed at the atmospheric condition and temperatures were ranged $25-33^{\circ} \mathrm{C}$.

The volume of the aqueous ethanol was obtained by calculating the difference between the total and the initial oil volumes. The amount of pure ethanol was obtained by multiplying its percentage with the volume of the aqueous ethanol, water as its residual difference. The blending process was initiated by adding $98 \%$ ethanol to gasoline.

The aqueous ethanol was added gradually while gently shaking the flask until a single phase of aqueous gasohol was formed. In this case, $0.05 \mathrm{~mL}$ of aqueous ethanol was required; therefore, the amount of pure ethanol was calculated by multiplying of the percentage (vol.\%) ethanol and its volume $(0.98 \times 0.05 \mathrm{~mL}=0.048 \mathrm{~mL})$, while the water content was the volume difference between aqueousand pure ethanol $(0.05-0.048 \mathrm{~mL}=0.01 \mathrm{~mL})$.

The compositions were defined as the volume ratios of the gasoline, pure ethanol, and water. The volume of the three components was divided by that of the gasoline to simplify the values. The minimum ethanol volume in the compositions was required to form a single-phase blend with gasoline, which will be explained entirely in the Discussion section. Similar procedures were carried out for all the ethanol solutions with different concentrations.

\subsection{Instrumentation and measurement}

All the parameters used in this study were measured as recommended by the American Society for Testing and Materials (ASTM). The experiments were conducted at the Oil and Gas Laboratory, Energy and Mineral Polytechnics, Cepu Blora Central Java, and at Samarinda Polytechnics, East Kalimantan Indonesia.

The parameters characterized are as follows: density $\left(15^{\circ} \mathrm{C}\right.$; D4052; Koehler; New York USA ), RON (D2699, D2700, and D613), viscosity $\left(40^{\circ} \mathrm{C}\right.$; D445; KV1000; Kohler; New York USA), ASTM color (D1599; K13200 petroleum colorimeter; Koehler; New York USA), flash point PMCC (D93; Electric Pensky-Martens; SDM Torino, Italy), Reid vapor pressure (D323; Koehler; New York USA), pour point (D97; Lawler manufacturing company; Indianapolis USA), and distillation (D86; Koehler; New York USA).

The aqueous ethanol concentration was $96 \%$. The instrument used for RON, MON, and (R+M)/2 measurements had the Octane Analyzer (K88600 Koehler Company).

\subsection{Triangular analysis}

The template of the triangular graph was obtained freely online from http://www.phasediagram. $\mathrm{dk} /$ download/TriangularExcelTemplate.htm. The proportions of the three components, gasoline, pure ethanol, and water, were substituted in the template and analyzed.

\section{Results and discussions}

\subsection{Compositions of the gasoline (RON 90/92)-pure ethanol-water}

The prepared fuel blends can serve as substitutes for fossil fuel, which is still the primary energy source for cars and industrial engines. Indonesia is on the brink of an energy crisis since it is a major global importer of fossil-based oil. Besides, petroleum and coal are the most significant contributors to $\mathrm{CO}_{2}$, which causes global warming. 
Ethanol, derived from renewable resources such as sugar, starch, and cellulose, is an optional component of blended fuels, which can serve as a substitute for fossil fuel. Thus, ethanol utilization can decrease $\mathrm{CO}_{2}$ emissions in the atmosphere. The most important advantage is that the gases emitted by an engine powered by blended fuel can be recycled by planting trees, which also act as sources of raw materials.

The utilization of the mixed fuel with a high concentration of aqueous ethanol is challenging because most of the engines in use were designed and constructed to function only on pure petroleum; however, if the blended fuel must be used, the percentage of ethanol must be below $10 \%$.

Table 1. Compositions of the blended fuel of gasoline (ron 90), pure ethanol, and water in a single-phase solution

\begin{tabular}{|c|c|c|c|c|c|c|c|c|c|}
\hline \multirow{3}{*}{ Et. $(\%)$} & \multicolumn{3}{|c|}{ Volume Ratio (v) } & \multicolumn{3}{|c|}{ Compositions (v) } & \multicolumn{3}{|c|}{ Compositions (\%v/v) } \\
\hline & \multirow{2}{*}{ Gas 90} & \multirow{2}{*}{$\begin{array}{c}\text { Pure } \\
\text { Et. }\end{array}$} & \multirow{2}{*}{ Wat } & & & & & & \\
\hline & & & & Gas 90 & Pure Et. & Wat & Gas 90 & Pure Et. & Wat \\
\hline 98.00 & 7.00 & 0.05 & 0.01 & 1.00 & 0.01 & 0.00 & 99.21 & 0.69 & 0.10 \\
\hline 97.00 & 7.00 & 0.97 & 0.03 & 1.00 & 0.13 & 0.00 & 88.18 & 11.46 & 0.35 \\
\hline 96.00 & 7.00 & 1.92 & 0.08 & 1.00 & 0.27 & 0.01 & 78.06 & 21.08 & 0.86 \\
\hline 95.00 & 7.00 & 2.85 & 0.15 & 1.00 & 0.40 & 0.02 & 70.37 & 28.15 & 1.48 \\
\hline 94.00 & 7.00 & 5.64 & 0.36 & 1.00 & 0.80 & 0.05 & 54.02 & 43.22 & 2.76 \\
\hline 93.00 & 7.00 & 9.30 & 0.70 & 1.00 & 1.30 & 0.10 & 41.67 & 54.17 & 4.17 \\
\hline 92.00 & 7.00 & 15.64 & 1.36 & 1.00 & 2.23 & 0.19 & 29.21 & 65.13 & 5.67 \\
\hline 91.00 & 7.00 & 24.57 & 2.43 & 1.00 & 3.51 & 0.35 & 20.59 & 72.27 & 7.14 \\
\hline 90.00 & 7.00 & 21.60 & 2.40 & 1.00 & 3.08 & 0.34 & 22.61 & 69.64 & 7.75 \\
\hline 89.00 & 7.00 & 30.26 & 3.74 & 1.00 & 4.32 & 0.53 & 17.08 & 73.80 & 9.12 \\
\hline 88.00 & 7.00 & 41.36 & 5.64 & 1.00 & 5.90 & 0.81 & 12.98 & 76.56 & 10.46 \\
\hline 87.00 & 7.00 & 44.62 & 6.37 & 1.00 & 6.37 & 0.91 & 12.08 & 76.93 & 10.99 \\
\hline 86.00 & 7.00 & 52.46 & 8.54 & 1.00 & 7.49 & 1.22 & 10.30 & 77.14 & 12.56 \\
\hline 85.00 & 7.00 & 56.95 & 10.05 & 1.00 & 8.13 & 1.44 & 9.46 & 76.94 & 13.59 \\
\hline 84.00 & 7.00 & 58.80 & 11.20 & 1.00 & 8.40 & 1.60 & 9.09 & 76.36 & 14.55 \\
\hline 80.00 & 7.00 & 81.60 & 20.40 & 1.00 & 11.65 & 2.91 & 6.43 & 74.85 & 18.72 \\
\hline
\end{tabular}

Therefore, it is necessary to design new engines, which can be powered by fuels with high ethanol content and a small amount of water. The application of the blended fuel, gasoline, and alcohol (gasohol) requires that the purity of ethanol is at least $99.5 \%$. The most severe problems are the high cost of preparing absolute alcohol and the fact that technology is currently undergoing development.

However, the problem can be solved by employing aqueous gasohol whose ethanol concentration is below 96\%; moreover, the technology for such an application is well-established and can be applied in small industries, villages, and remote areas.

The present finding leads to the introduction of the new fuel blends of gasoline and aqueous ethanol, which is considered cost-effective. The gasoline with RONs of 90 and 92 was mixed with aqueous ethanol to produce a new single-phase substance called aqueous gasohol, as shown in the table below. 
Table 2. Compositions of the blended fuel of the gasoline (ron 92), pure ethanol, and water in a single-phase solution

\begin{tabular}{|c|c|c|c|c|c|c|c|c|c|}
\hline \multirow{3}{*}{$\begin{array}{l}\text { Et. } \\
\%\end{array}$} & \multicolumn{3}{|c|}{ Volume Ratio (v) } & \multirow{2}{*}{\multicolumn{3}{|c|}{ Composition (v) }} & \multirow{2}{*}{\multicolumn{3}{|c|}{ Composition (in \%v/v) }} \\
\hline & \multirow{2}{*}{ Gas 92} & \multirow{2}{*}{ Pure Et } & \multirow{2}{*}{ Wat } & & & & & & \\
\hline & & & & Gas 92 & Pure Et. & Wat & Gas 92 & Pure Et. & Wat \\
\hline 97.00 & 7.00 & 1.94 & 0.06 & 1.00 & 0.28 & 0.01 & 77.76 & 21.54 & 0.70 \\
\hline 96.00 & 7.00 & 2.88 & 0.12 & 1.00 & 0.41 & 0.02 & 70.03 & 28.78 & 1.19 \\
\hline 95.00 & 7.00 & 10.45 & 0.55 & 1.00 & 1.49 & 0.08 & 38.88 & 58.05 & 3.07 \\
\hline 94.00 & 7.00 & 13.16 & 0.84 & 1.00 & 1.88 & 0.12 & 33.33 & 62.67 & 4.00 \\
\hline 93.00 & 7.00 & 16.74 & 1.26 & 1.00 & 2.39 & 0.18 & 28.00 & 66.96 & 5.04 \\
\hline 92.00 & 7.00 & 20.24 & 1.76 & 1.00 & 2.89 & 0.25 & 24.14 & 69.80 & 6.06 \\
\hline 91.00 & 7.00 & 29.12 & 2.88 & 1.00 & 4.16 & 0.41 & 17.95 & 74.67 & 7.38 \\
\hline 90.00 & 7.00 & 31.50 & 3.50 & 1.00 & 4.50 & 0.50 & 16.67 & 75.00 & 8.33 \\
\hline 89.00 & 7.00 & 37.38 & 4.62 & 1.00 & 5.34 & 0.66 & 14.29 & 76.29 & 9.43 \\
\hline 88.00 & 7.00 & 41.36 & 5.64 & 1.00 & 5.91 & 0.81 & 12.96 & 76.59 & 10.45 \\
\hline
\end{tabular}

The ethanol obtained had purity levels between 80 and $96 \%$ depending on the set column temperature. Ethanol solutions whose concentrations were in the range of 97-98 were obtained through an adsorption technique using lime particles.

The blending technique between gasoline and ethanol was simple, and it did not require a synthetic surfactant, which was expensive. The process was initiated by preparing the gasoline, ethanol, and flask used. If ethanol with a specific concentration was not available, the one with the relatively high purity was mixed with water. The next step was the blending of gasoline and aqueous ethanol manually.

The compositions (in volume unit) of the gasoline (RON 90)-pure ethanol-water mixture blended at room temperature, $25-33^{\circ} \mathrm{C}$ into single-phase aqueous gasohol are displayed in Table 1 . When $98 \%$ ethanol was used in the blending, the composition ratio of gasoline, pure ethanol, and water were 7:0.048:0.01, which was simplified and written as 1:0.007:0.001, after rounding the values. By adopting a similar procedure and using 97, 96, and 95\% concentrations, the compositions of the components changed significantly to 1:0.130:0.004, 1:0.270:0.011, and 1:0,400:0.021, respectively.

When ethanol of low purity was used, a significant amount of ethanol was added to gasoline to form the emulsion, as shown in Tables 1 and 2. There were apparent differences between the oils whose RONs were 90 and 92, in response to the addition of low-purity ethanol. At concentrations of 95 and 94\%, the amounts of ethanol required to form single-phase substances with gasoline of RON 90 were 2.85 and $5.64 \mathrm{~mL}$. In contrast, those with gasoline of RON 92 were 10.45 and $13.16 \mathrm{~mL}$, respectively. If expressed in terms of the compositions, which are described above, they can be written as 1:0.400:0.021 and 1:0.800:0.051, as well as 1:1.493:0.079 and 1:1.880:0.120, respectively. The 93\% aqueous ethanol, gasoline (RON 90), pure ethanol, and water formed an emulsion with a 1:1.300:0.100, while the mixture with gasoline (RON 92) had a composition ratio of 1:2.391:0.180.

The present invention was tailored so that the gasohol formed in a single phase must have the exact composition of gasoline and aqueous ethanol, or gasoline, pure ethanol, and water. If the amount of ethanol is less than the minimum composition as described in Tables 1 and 2, a single-phase will not be formed. However, if the amount of ethanol increases continually from the state of a single-phase emulsion, the components constituting the gasohol will not be separated. 


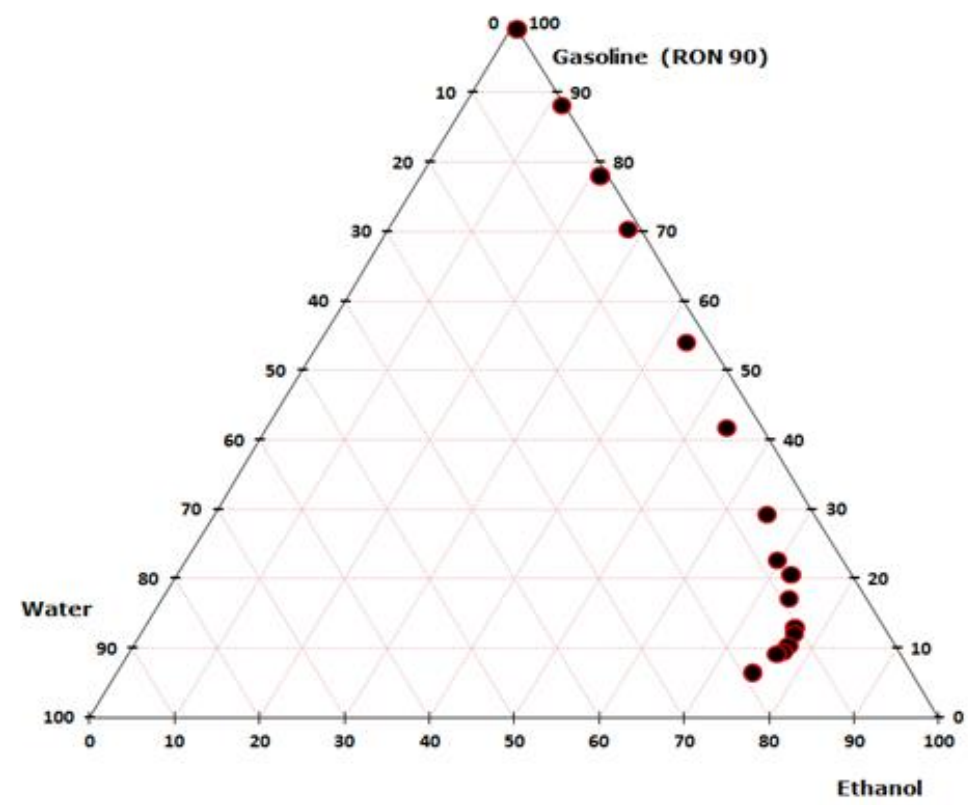

Figure 1. Triangular graphs of gasoline (RON 90)-ethanol-water under atmospheric condition

As shown in the data, the ethanol concentration change significantly influences the composition or amount of gasoline, ethanol, and water. The $1.94 \mathrm{~mL}$ ethanol with a $97 \%$ concentration, for example, requires $7 \mathrm{~mL}$ of gasoline (RON 92) and $0.06 \mathrm{~mL}$ to form a single-phase aqueous gasohol substance.

If the concentration is decreased to $96 \%$, the volume of ethanol needs to be increased to $2.88 \mathrm{~mL}$, and that of water increased to $0.12 \mathrm{~mL}$. The extreme increase occurs when using $95 \%$ ethanol, whose volume and water are 10.45 and $0.55 \mathrm{~mL}$, respectively. The dissolution of aqueous ethanol in gasoline depends on its purity. The purity at $80 \%$ concentration is the minimum allowed for the formation of a single-phase emulsion. At a concentration of less than $80 \%$, the ethanol dissolution with gasoline is stopped owing to the imbalanced forces between the water weight and attractive molecular strength. The gravitational force acting on the water molecules between aqueous ethanol molecules is greater than the partial attractive force acting between the polar poles of the gasoline and ethanol molecules. The lesser the uniformity of the pure ethanol and gasoline blend, the lower the possibility that a singlephase emulsion (gasohol) of aqueous ethanol and gasoline forms.

As seen from the data shown in both tables, there is a significant difference in the amounts of aqueous ethanol dissolved in gasoline RON 90 and RON 92. Generally, the composition of ethanol dissolved in gasoline RON 92 is higher than that in RON 90. The fuel blends measured were gasoline (RON 90)-ethanol-water and gasoline (RON 92)-ethanol-water whose compositions were 70.03, 28.78, and $1.19 \%$; and $78.06,21.08$, and $0.86 \%$, respectively for ethanol $96 \%$.

Since the blended fuels in this work do not require absolute ethanol, the chain of procedure on an industrial scale is not complicated. To produce aqueous ethanol, the distillation columns have to be installed in locations close to the raw materials' sources, such as palm, tubers, corn, or cassava plantations. The farmers can directly produce the aqueous ethanol from a yeast-treated liquor to reduce the cost of liquor preparation. The price of a reflux column with a diameter of 4 in and length of $2 \mathrm{~m}$, made from a magnetic SS, is about US\$ 1200 per unit, including the boiler and its construction. The farmer should sell the product directly to the industry without third parties. 


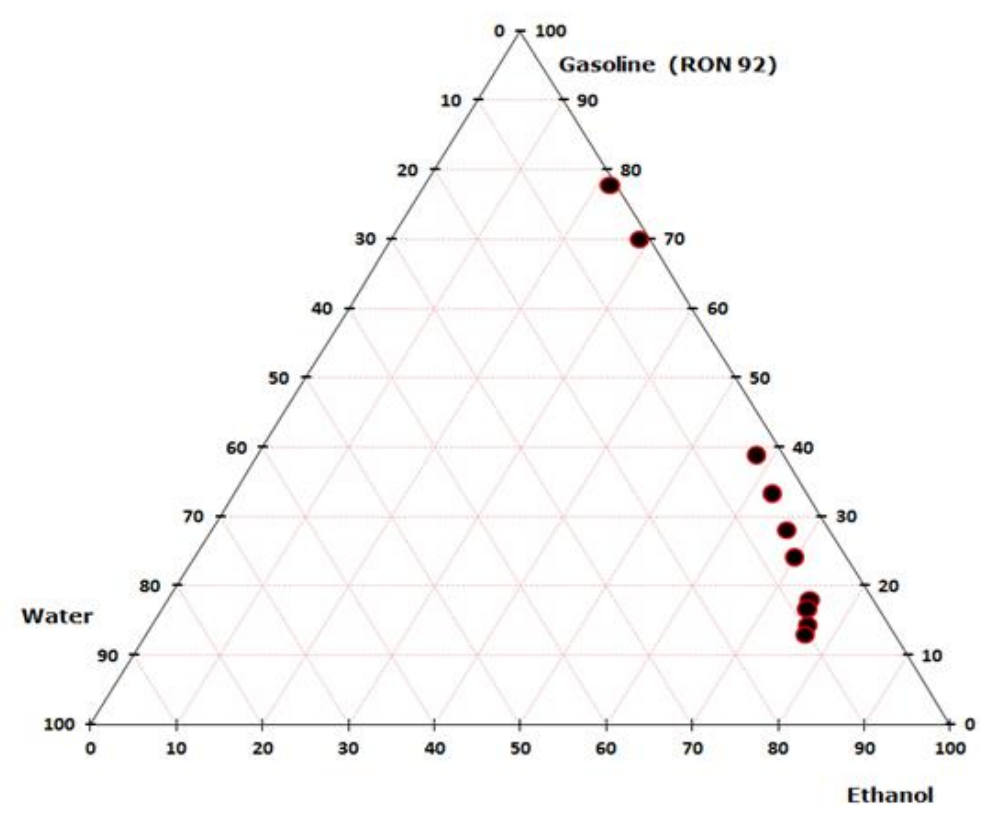

Figure 2. Triangular graphs of gasoline (RON 90)-ethanol-water

(A) and gasoline (RON 92)ethanol-water, under atmospheric condition

The techniques used, i.e., fermentation and distillation, are well established, and they do not require high-precision instruments; therefore, scaling up the present product would be met with stiff competition. The steps in industrial-scale production are summarized as follows: preparation of raw materials, yeast treatment of the sugar hydrolyzed from starch-based biomass, and distillation to produce the aqueous ethanol. These processes are conducted in villages where small companies are located. Subsequently, the aqueous ethanol is shipped to the blending center run by a national oil company, called PERTAMINA, in Indonesia. The blending process is not complicated as it involves only the mixing the gasoline (RONs of 90 and 92) and the aqueous ethanol in an exact composition ratio as explained previously in this paper.

\subsection{The triangular graphs analysis}

The triangular graphs of the compositions of gasoline (RON 90)-pure ethanol-water and gasoline (RON 92)-ethanol-water, in which pure ethanol is utilized in $\% \mathrm{v} / \mathrm{v}$, are presented in Figure 1 and 2. The compositions measured in a single phase are marked with a solid circle. The experiment was conducted at a temperature of $30^{\circ} \mathrm{C}$ and an atmospheric pressure of $1 \mathrm{~atm}$.

The dots displayed on the graphs represent equilibria states, during which the components form a single phase. The shapes of the two graphs are quite similar. However, the ethanol with a relatively low concentration in a single phase was different, whereby gasoline RON 90 dissolved entirely at least in $80 \%$ ethanol, while gasoline RON 92 dissolved in $88 \%$ ethanol. The areas of the graph where the components were separated into two phases are located on the left side (before reader), while the regions of the graph, where the components form a single phase, are on the right side, as shown in the figure. It was also found that the composition $(\% \mathrm{v} / \mathrm{v})$, at which gasoline and wet ethanol formed a single-phase, is dependent on the ethanol concentration and type of gasoline employed, as shown in Tables 1 and 2 and in Figure 1. The ranges of compositions in which pure ethanol, gasoline (RON 90), and water blended entirely were $0.69-74.85 \%, 6.43-99.21$, and $0.10-18.72 \%$, respectively. The highest water content mixed with gasoline was $18.72 \%$ at the least ethanol concentration, i.e., $80 \%$.

When gasoline (RON 92) was applied to the blending, the composition changed significantly. The least ethanol concentration was different compared to that in the case of gasoline (RON 90), as shown in Figure 2. When $88 \%$ of ethanol was used, gasoline, pure ethanol, and water were mixed perfectly with compositions of $12.96,76.59$, and 10.45 , respectively, which were the least concentrations. The ranges of the compositions in which the gasoline (RON 92), pure ethanol, and water blended thoroughly into a single phase, were $12.96-77.76 \%, 21.54-76.59$, and $0.70-10.45 \%$, respectively. 
Ethanol (95 and 96\%) dissolved entirely with gasoline (RON 92), and their compositions were 38.88 (gas), 58.05 (ethanol), and 3.07\% (water), and 70.03, 28.78, and 1.19\%. Since the investigation in this study has not been conducted previously, comparative research with other references is not presented.

\subsection{The fuel parameters}

The fuel parameters characterized by the blended fuels, gasoline (RON 90)-pure ethanol-water, and gasoline (RON 92)-pure ethanol-water, in which the concentration of ethanol employed was $96 \%$ are shown in Table 3. The density and specific gravity (SG) of the gasoline (RON 90)-pure ethanol-water fuel blends were both $0.77 \mathrm{~g} / \mathrm{cc}$, similar to those of gasoline (RON 92)-pure ethanol-water, which are $0.78 \mathrm{~g} / \mathrm{cm}^{3}$. These values are higher than those in previous work [25]. The differences were mainly caused by the presence of a small amount of water in the blended fuel.

The viscosity, ASTM color, flash point and pour point of both fuels were not measurable in this study. The Reid vapor pressures (RVP) of these fuels were observed as 58.00 and $41.00 \mathrm{kPa}$; notably, it had been studied that the gasohol containing $2.50 \%$ of industrial ethanol $96 \%$ gives an RPV of 56.54 $\mathrm{kPa}$ [23]. The RPV standard issued by the US Environmental Protection Agency (EPA) is in the range of 54-62 kPa, which is comparable to that of the present investigation.

The standard fuels used in this study showed that the RON, MON, and (R+M)/2 were 106.6, 93.6, and 100, respectively, while the standard blended fuels were recorded as 104.9, 93, and 96.5, respectively. The RON of the first fuel was 95.80, and that of the second blended fuel was slightly higher (97.40).

Conversely, the MON quantities of both fuels were detected at 99.40 and 101.00, respectively. Their octant value averages defined as $(\mathrm{R}+\mathrm{M}) / 2$ were 97.60 and 99.20 , respectively. These results are slightly different from those of a previous study [26]. Furthermore, the RON and MON values increased significantly from pure gasoline with RONs of 90 and 92 . This finding indicates that the aqueous $96 \%$ ethanol containing water of 0.86 and $1.19 \%$ affects the RON and MON quantities positively, and the presence of water is not detrimental to those parameters. In this work, it was also found that ethanol could improve the RON and MON parameters, which is consistent with some references cited.

Meanwhile, the API parameters for both blended fuels were recorded at 56.80 and 54.30. According to a previous investigation, the API gravity parameter for an $80 \%$ gasoline and $20 \%$ ethanol fuel blend was around 55.8 [27], which is very close to the value obtained in the present work.

Table 3. Fuel parameters measured for the gasoline (ron 90)-ethanol-water and gasoline (ron 92)ethanol-water fuel blends in a single phase, in which $96 \%$ ethanol was employed

\begin{tabular}{|c|c|c|c|c|}
\hline Parameter & $\begin{array}{l}\text { Gasoline (RON90)-ethanol- } \\
\text { water }\end{array}$ & Gasoline (RON 92)-ethanol-water & Unit & ASTM \\
\hline Density $\left(15^{\circ} \mathrm{C}\right)$ & 0.77 & 0.78 & $\mathrm{~g} / \mathrm{cm}^{3}$ & $\mathrm{D} 4052$ \\
\hline SG & 0.77 & 0.78 & $\mathrm{~g} / \mathrm{cm}^{3}$ & $\mathrm{D} 4052$ \\
\hline Viscosity $\left(40^{\circ} \mathrm{C}\right)$ & - & - & $\mathrm{mm}^{2} / \mathrm{s}$ & D445 \\
\hline ON Analyzer & 89.57 & 87.90 & - & - \\
\hline ASTM Color & - & - & - & D1500 \\
\hline $\begin{array}{l}\text { Flashpoint } \\
\text { PMCC }\end{array}$ & - & - & ${ }^{\circ} \mathrm{C}$ & D93 \\
\hline $\begin{array}{l}\text { Reid vapor } \\
\text { pressure }\end{array}$ & 58.00 & 41.00 & $\mathrm{kPz}$ & D323 \\
\hline Pour point & - & - & ${ }^{\circ} \mathrm{C}$ & D97 \\
\hline $\mathrm{API}\left(15^{\circ} \mathrm{C}\right)$ & 56.80 & 54.30 & & AJSA106 \\
\hline RON (R) & 95.80 & 97.40 & - & D2699/D2700 \\
\hline MON (M) & 99.40 & 101.00 & - & D2699/D2700 \\
\hline$(\mathrm{R}+\mathrm{M}) / 2$ & 97.60 & 99.20 & - & D2699/D2700 \\
\hline
\end{tabular}

API: American Petroleum Institute gravity; Motor Octane Number (MON); Anti-Knock Index (AKI) or average value, $(\mathrm{R}+\mathrm{M}) / 2$ 


\subsection{The distillation analysis}

The distillation properties of the blended fuels, gasoline (RON 90)-ethanol-water and gasoline (RON 92)-ethanol-water, in a single-phase are presented in Table 4. The data shows that both blended fuels boil at similar temperatures, with an identical initial boiling point (IBP) of $45^{\circ} \mathrm{C}$. This indicates that the fuels have fractions that have identical structures and carbon chains. When $5 \%$ of the fuels evaporated, the boiling points began to change. The gasoline (RON 90), pure ethanol, and water blend boiled at $48^{\circ} \mathrm{C}$, while the gasoline (RON 92), pure ethanol, and water blend boiled at $52^{\circ} \mathrm{C}$.

The higher the amount of evaporated fuel, the higher the temperature difference between the two fuels being boiled. Although when $60 \%$ of the fuel composition disappeared, the temperature difference began to decline, as shown in the table.

The boiling points in ${ }^{\circ} \mathrm{C}$ of the gasoline (RON 90)-ethanol-water and gasoline (RON 92)-ethanolwater blends with 70,80 , and $90 \%$ fuel evaporation are given as $(74,77),(78,80)$, and $(80,81)$. It was found that the final boiling points of the two fuel blends were different, i.e., 91 and $83{ }^{\circ} \mathrm{C}$. This is an indication that the remnant of the final fractions had different structures or types of petrol. The residue of the first blend was $0.10 \mathrm{~mL}$ compared to that of the second blend, which was $1.1 \mathrm{~mL}$. Compared to a review by [28] using pure gasoline and $99.65 \%$ ethanol, the distillation quantities at the boiling point and percentage of the evaporated petrol in this study are profoundly different. The other distillation test carried previously showed a graph trend close to that of this work, although there were differences in terms of the evaporated petrol and boiling temperatures. The variation trend was mainly caused by the fractions contained inside fuel in which the boiling points are different. The gasoline and ethanol fuel blends containing water significantly influenced the distillation parameter.

Table 4. Distillation properties of the gasoline (ron 90)-ethanol-water and gasoline (ron 92)-ethanol-water blends in a single phase

\begin{tabular}{|c|c|c|c|}
\hline \multirow{2}{*}{ No } & \multirow{2}{*}{ Testing } & Gasoline (RON 90)-ethanol-water & Gasoline (RON 92)-ethanol-water \\
\cline { 3 - 4 } & & ${ }^{\circ} \mathrm{C}$ & ${ }^{\circ} \mathrm{C}$ \\
\hline 1 & IBP & 45 & 45 \\
\hline 2 & $5 \%$ & 48 & 52 \\
\hline 3 & $10 \%$ & 50 & 55 \\
\hline 4 & $20 \%$ & 55 & 60 \\
\hline 5 & $30 \%$ & 58 & 65 \\
\hline 6 & $40 \%$ & 63 & 69 \\
\hline 7 & $50 \%$ & 66 & 73 \\
\hline 8 & $60 \%$ & 71 & 75 \\
\hline 9 & $70 \%$ & 74 & 77 \\
\hline 10 & $80 \%$ & 78 & 80 \\
\hline 11 & $90 \%$ & 80 & 81 \\
\hline 12 & FBP & 91 & 83 \\
\hline 12 & Distillate, $\%$ & 99.00 & 92.00 \\
\hline 13 & Residue $(\mathrm{mL})$ & 0.10 & 1.1 \\
\hline
\end{tabular}

IBP: Initial boiling point; FBP: Final boiling point; $5 \%: 5 \%$ of fuel evaporated

\section{Conclusions}

Gasoline with RONs of 90 and 92 was blended successfully with ethanol, whose purity was below 98\% to form aqueous gasohol. The present work relates to the compositions of the gasoline (RON 90)pure ethanol-water and gasoline (RON 92)-pure ethanol-water fuel blends. The previous technology used in producing gasohol generally employed pure alcohol, which was very expensive; besides, technology is undergoing development in Indonesia and other countries. Thus, it is necessary to prepare gasoline and aqueous ethanol fuel blend; moreover, this method is cheap. Expectedly, the application of the aqueous fuel blends with water is still a challenge for engineers globally. Most of the conventional engines are designed and constructed to work without water in the fuel. The results showed that ethanol solutions with concentrations between 80 and $98 \%$ were entirely dissolved with gasoline in an exact composition. The composition ranges of gasoline (RON 90), pure ethanol, and water at the instance of forming a single-phase mixture using ethanol with concentrations in the range 
of $80-98 \%$ were $9.46-99.21 \%, 0.69-76.94 \%$, and $0.10-13.59 \%$, respectively, compared to those of gasoline (RON 92), pure ethanol, and water using 80-98\% ethanol, which was $12.96-77.76 \%, 21.54-$ $76.58 \%$, and $0.70-10.45 \%$, respectively. It was also discovered that the change in the ethanol concentration could be significantly influenced by the compositions of gasoline, ethanol, and water while forming the single-phase gasohol. The addition of ethanol after the single-phase formation did not lead to the separation of the components of gasoline and aqueous ethanol. However, high amounts of ethanol in the single-phase aqueous emulsion could not be achieved. It was found that the fuel and distillation parameters changed in the pure ethanol and gasoline, owing to the presence of ethanol and a small amount of water, although the change was within the permitted range for fuels.

Acknowledgments. The authors would like to acknowledge the Higher Education Department of the Indonesian Government and Sam Ratulangi University for their financial support and Professor Ronny Purwadi at the Bioenergy Lab, Chemical Engineering of ITB Bandung, who assisted and provided the authors with the preparation and measurement of the blended fuels. We give special gratitude to the institutions, PEM AKAMIGAS Cepu Blora, Central Java, Chemical Engineering of ITS Surabaya, to measure the fuel parameters.

\section{References}

1. TEPELUS, A., ROSCA, P., DRAGOMIR, R., Biojet from Hydroconversion of Camelina Oil Mixed with Straight Run Gas Oil, Rev. Chim., 70(9), 2019, 3284-3291.

2.ABDULLAH A., ARIYANTI, D., Enhancing ethanol production by fermentation using saccharomyces cereviseae under vacuum condition in batch operation, Int. J. Renew. Energy Dev., 1, 2012, 6-9.

3. CIOROIU, D. R., KONCSAG, C. I., GUDOVAN, D., DOBRE, T., Fresh Ulva Lactuca Alcoholic Fermentation Products and yields, Rev. Chim., 69(5), 2018, 1226-1228.

4. PHAM, T. T. H., KIM, T. H., UM, B. H., Recovery of Acetic Acid from An Ethanol Fermentation Broth by Liquid-Liquid Extraction (LLE) Using Various Solvents, Korean Chem. Eng. Res., 53(6), 2015, 695-702.

5. MUHARJA, M., UMAM, D., K. PERTIWI, D., ZUHDAN, J. NURTONO, T., WIDJAJA, A., Enhancement of sugar production from coconut husk based on the impact of the combination of surfactant-assisted subcritical water and enzymatic hydrolysis, Bioresour. Technol., 274, 2019, 89-96.

6. AMIGUN, B., VON BLOTTNITZ, H., Investigation of Scale Economies for African Biogas Field Study, Sol. Energy, 82(4), 2007, 911-917.

7. WIDJAJA, A., AGNESTY, S.Y., SANGIAN, H.F., GUNAWAN, S., Application of Ionic Liquid [DMIM]DMP Pretreatment in the Hydrolysis of Sugarcane Bagasse for Biofuel Production

Bull. Chem. React. Eng. Catal., 10(1), 2015, 70-77.

8. EBRAHIMI, M., CAPARANGA, A.R., ORDONO, E.E., VILLAFLORES, O.B., Evaluation of Organosolv Pretreatment on The Enzymatic Digestibility of Coconut Coir Fibers and Bioethanol Production Via Simultaneous Saccharification and Fermentation, Renew. Energy., 109, 2017, 41-48.

9. DUMITRU, M.G., Degumming Role of Sunflower Oil (Helianthus annuus) on Biodiesel Quality, Rev.Chim., 70(1), 2019, 54-58.

10. DRAGOMIR, R.E., ROSCA, P., Rosca Biofuel from Hydroprocessing Fish Oil, Rev. Chim., 71(1), 2020, 176-185.

11 AHN, Y., CHUNG, Y., KWON, Y., Immobilization of Glucose Oxidase using Branched Polyethyleneimines of Various Molecular Weights for Glucose Based Biofuel Cell, Korean Chem. Eng. Res., 54(5), 2016, 693-697.

12. MORALES, J. E. R., LÓPEZ, F. R., The Political Economy of Bioenergy in The United States: A Historical Perspective Based on Scenarios of Conflict and Convergence, Energy Res. Soc. Sci., 27, 2017, 141-150. 
13. BELINCANTA, J., ALCHORNE, J.A., DA SILVA, M.T., The Brazilian Experience With Ethanol Fuel: Aspects of Production, Use, Quality and Distribution Logistics, Braz. J. Chem. Eng., 33, 2016, 1091-1102.

14. OBIDZINSKI, K., ANDRIANI, R,.KOMARUDIN, H., ANDRIANTO A., Environmental and Social Impacts of Oil Palm Plantations and their Implications for Biofuel Production in Indonesia, Ecol. Soc., 17(1):25, 2012, 1-19.

15. LANZANOVA, T.D.M., NORA, M.D., ZHAO, H., Performance and Economic Analysis of a Direct Injection Spark Ignition Engine Fueled with Wet Ethanol, Appl. Energy, 169, 2016, 230-239.

16. KHANNA, M. NUÑEZ, H. M., ZILBERMAN, D., Who Pays And Who Gains From Fuel Policies in Brazil?, Energy Econ., 54, 2016, 133-143.

17. ELFASAKHANY, A., The Effects of Ethanol-Gasoline Blends on Performance and Exhaust Emission Characteristics of Spark Ignition Engines, Int. J. Autom. Eng., 4, 2014, 609-620.

18. STOREY, J., BARONE, T,. NORMAN, K., LEWIS, S., Ethanol Blend Effects on Direct Injection Spark-Ignition Gasoline Vehicle Particulate Matter Emissions, SAE Int. J. Fuels Lubr., 3, 2010, 650659.

19. NEAGU, M., DINU, F., A Predictive Tool for Phase Separation in Ethanol-gasoline Blends, Rev. Chim., 64(10), 2013, 1160-1165.

20. DE DOZ, M.B.G., BONATTI, C.M., SÓLIMO, H.N., Water Tolerance and Ethanol Concentration in Ethanol-Gasoline Fuels at Three Temperatures, Energ Fuel., 18, 2004, 334-337.

21. RADU, A., PANTILE, V., RUSU, E., Use of E20 in a Spark Ignition Supercharged Engine, Rev. Chim., 64(2), 2013, 198-201.

22. SANGIAN, H.F., TAMUNTUAN, G. H, MOSEY, H.I.R., SUOTH, V., MANIALUP, B.H., J. Eng. Appl. Sci., 12, 2017, 7039-7046.

23.MURACHMAN, B., PRANANTYO, D., PUTRA, E.S., Study of Gasohol as Alternative Fuel for Gasoline Substitution: Characteristics and Performances, Int. J. Renew. Energy Dev., 3(3), 2014, 175 183.

24. WANG, C., ZERAATI-REZAEI, S., XIANG, L., XU, H., Ethanol Blends in Spark Ignition Engines: RON, Octane-Added Value, Cooling Effect, Compression Ratio, and Potential Engine Efficiency Gain, Appl. Energy., 191(1), 2017, 603-619.

25. KUBURI, L. S., OBADA, D. O., SAMOTU, I. A., CHIRA, C. V., OSUCHUKWU, O. A., JEREMIAH, M., Performance Characteristics of a Gasohol Fueled S.I Engine, IOSR J. Eng., 04(05), 2014, 36-41.

26. FOONG, T.M., MORGANTI, K.J., BREAR, M.J., DA SILVA, YANG, G.Y., DRYER, F.L., The Octane Numbers of Ethanol Blended with Gasoline and Its Surrogates, Fuel, 115, 2014, 727-739.

27. GUERRIERI, D.A., CAFFREY, P.J., RAO, V., Investigation Into the Vehicle Exhaust Emissions of High Percentage Ethanol Blends, SAE Tech. Pap., 950777, 1995, 85-95.

28. TÜRKÖZ, N., ERKUS, B., KARAMANGIL, M.I., SÜRMEN, A., ARSLANOGLU, N., Experimental Investigation of the Effect of E85 On Engine Performance and Emissions Under Various Ignition Timings, Fuel., 115, 2014, 826-832.

$\overline{\text { Manuscript received: } 10.02 .2020}$ 